\title{
MASALAH EMOSI DAN PERILAKU PADA PENDERITA TB ANAK
}

\author{
Giri Widakdo ${ }^{1)}$, Erni Rita ${ }^{2)}$, Indah Noviana Saputri, ${ }^{3)}$ \\ Tria Astika Endah Permatasari ${ }^{4)}$, Ika Kurniaty ${ }^{5}$ \\ 1,2,3 Fakultas Ilmu Keperawatan Universitas Muhammadiyah Jakarta \\ ${ }^{4}$ Fakultas Kedokteran dan KesehatanUniversitas Muhammadiyah Jakarta \\ ${ }^{5}$ Fakultas Teknik Universitas Muhammadiyah Jakarta \\ Email : giriwae@gmail.com
}

Diterima: Juni 2020, Diterbitkan: Juni 2020

\begin{abstract}
ABSTRAK
Salah satu dampak masalah emosi dan perilaku pada penderita TB anak adalah terganggunya produktivitas dan kualitas hidup termasuk pendidikan anak. Penelitian ini bertujuan untuk mengidentifikasi masalah emosi dan perilaku pada penderita TB anak di Wilayah Puskesmas Jakarta Pusat dan Puskesmas Jakarta Timur. Desain penelitian ini adalah crosseksional pada 91 penderita TB anak di tahun 2019 yang diukur dengan menggunakan Strength and Dfficulties Questionary (SDQ). Hasil penelitian menunjukkan analisis distribusi skor masalah dan perilaku penderita TB pada anak berdasarkan kovariat, yaitu : untuk masalah tingkah laku didapatkan pada kelompok abnormal baik untuk status gizi normal $(89,4 \%)$, riwayat kontak serumah $(57,6 \%)$ dan status TB negatif $(80,3 \%)$ dan untuk hubungan dengan teman sebaya, kelompok abnormal terbesar terdapat pada status gizi normal (92\%), riwayat kontak serumah (60\%) dan status TB negatif (84\%) serta skor kesulitan dalam kategori abnormal terdapat pada status gizi normal $(89,9 \%)$, riwayat kontak serumah $(60 \%)$ dan status TB negatif (80\%) Kesimpulan:. Distribusi skor SDQ dengan kovariat (Status Gizi, Riwayat kontak dan Status TB), untuk kategori abnormal terdapat pada: masalah tingkah laku teman sebaya dan skor kesulitan. Orang tua, guru atau puskesmas dapat menindak lanjuti hasil SDQ untuk mengantisipasi gangguan kesehatan mental pada anak.
\end{abstract}

Kata Kunci : TB anak, Emosi, Perilaku, SDQ

\section{ABSTRACT}

One of the effects of emotional and behavioral problems in children with TB is the disruption of productivity and quality of life including children's education. This study aims to identify emotional and behavioral problems in children with TB in the Central Jakarta Health Center and East Jakarta Health Center. The design of this study was cross-sectional in 91 pediatric TB patients in 2019 as measured using the Strength and Difficulties Questioner (SDQ).The results showed an analysis of the distribution of problem scores and behavior of TB sufferers in children based on covariates, namely: for behavior problems found in the abnormal group both for normal nutritional status (89.4\%), history of household contact (57.6\%) and TB status negative (80.3\%) and for relationships with peers, the largest abnormal group was found in normal nutritional status (92\%), family contact history (60\%) and negative TB status (84\%) and difficulty scores in the abnormal category were in normal nutritional status (89.9\%), household contact history (60\%) and negative TB status (80\%.)Conclusion: The distribution of SDQ scores with covariates (Nutritional Status, Contact History and TB Status), for the abnormal categories are: peer behavior problems and difficulty scores. Parents, teachers or health centers can follow up on $S D Q$ results to anticipate mental health disorders in children.

Keywords: Child TB, Emotion, Behavior, $S D Q$ 


\section{PENDAHULUAN}

Kualitas hidup anak dapat menentukan kemajuan keluarga, masyarakat, dan negara. Kesehatan mental anak juga sangat berpengaruh terhadap pertumbuhan kembang anak, salah satunya ditentukan oleh kesehatan, baik kesehatan fisik maupun mental. Masalah kesehatan mental pada anak salah satunya juga dapat disebabkan oleh faktor kesehatan fisik, seperti penyakit kronis tuberculosis (TB anak), dari sepuluh penderita penyakit kronis, dua sampai lima penderita akan mengalami gangguan mental emosional. Responden yang menderita satu penyakit kronis berisiko 2,6 kali lebih besar untuk mengalami gangguan mental emosional (Widakdo \& Besral, 2013). Anak dengan gangguan/masalah kesehatan mental akan menyebabkan rendahnya percaya diri serta kemampuan mereka untuk beradaptasi dengan lingkungan sangat tertutup. Hal ini dapat memberi dampak negatif terhadap emosi dan perilaku anak.

Masalah emosi dan perilaku terhadap anak merupakan masalah yang cukup serius karena berdampak terhadap psikologis, serta menyebabkan terganggunya produktivitas serta kualitas hidup termasuk pendidikan anak. Pendidikan pada masa kanak-kanak yang penting, karena rangsangan yang diterima pada masa kanak-kanak akan menentukan perkembangan selanjutnya. Pandangan psikologi rentang kehidupan (life-span perspective) yang mengatakan bahwa perkembangan manusia merupakan suatu yang saling keterkaitan antara tahap-tahap perkembangan satu dengan lainnya. Keberhasilan atau kegagalan disuatu tahap sanagat berpengaruh terhadap perkembangan emosi (Wiguna, 2010).

Menurut Goleman (2009) emosi disebut sebagai kegiatan atau pergolakan pikiran, perasaan, nafsu, setiap keadaan mental yang hebat atau meluap-luap. Suatu perasaan yang bergejolak dari dalam diri dapat berupa perasaan senang, marah, sedih, terharu, dan sebagainya, emosi ini dapat timbul setiap kali individu mendapatkan rangsangan yang dapat mempengaruhi kondisi jiwa dan dapat menimbulkan gejolak dari dalam sehingga menimbulkan gangguan mental dan emosi pada anak.

Anak merupakan masa emas di mana anak mengalami perubahan dan perkembangan yang pesat serta otak anak akan secara cepat menangkap dan mengingat apa yang dilihat, dirasa, dan didengar serta memiliki kepekaan dalam berbagai aspek perkembangan yaitu masa awal perkembangan kemampuan fisik motoric, kognitif, bahasa, dan sosial emosional (Dini, 2017). Pentingnya deteksi dini sebelum anak memasuki masa sekolah, terhadap masalah emosional dan tingkah laku adalah hal penting untuk mencegah gangguan perilaku.

Dalam (World Health Organization (WHO), 2016) satu dari empat orang di dunia terjangkit gangguan mental atau neurologis dalam beberapa waktu di dalam hidup mereka. Publikasi yang sama menyebutkan sekitar 450 juta orang Indonesia saat ini menderita gangguan kesehatan mental emosi, dan hampir 1 juta orang melkukan bunuh diri dalm setiap tahun. Di Indonesia sendiri, dari hasil Riset Kesehtan Dasar (Riskesdas) 2013, dikombinasikan dengan data rutin dari Pusdatin dengan waktu yang disesuaikan, prevalensi gangguan mental emosional yang ditunjukan dengan gejala-gejala depresi dan kecemasan sebesar 6\% untuk usia 15 tahun ke atas atau sekitar 14 juta orang. Sedangkan prevalensi gangguan jiwa berat seperti skizofrenia adalah 1,7 per 1000 penduduk atau sekitar 400.000 orang.

Berdasarkan peneliatian yang dilakukan oleh (Luh Gede, 2014) fenomena yang terjadi pada penelitian yang dilakukan, hasil penelitian lain di India menggambarkan prevalensi gangguan mental dan emosional pada anak usia 0-16 tahun sebesar 12,5\%. Dari hasil penelitian lain yang dilakukan oleh Wiguna, Manengkei, Amela, Rheza, dan Hapsari (2010) menjelaskan bahwa masalah mental emosi utama pada anak usia sekolah adalah 
masalah hubungan teman sebaya $(54,8 \%)$ dan diikuti oleh masalah emosi dengan presentase sebesar (42,2\%) (Wiguna, 2010).

Satu setengah juta anak dan remaja di Amerika Serikat dilaporkan oleh orang Tanya memiliki masalah emosional, perkembangan dan perilaku yang persisten. Sebagai contoh, $41 \%$ orang tua di Amerika Serikat khawatir anaknya mengalami kesulitan belajar dan 36\% khawatir akan mengalami gangguan depresi atau ansietas. Di Singapura, 12,5\% anak usia 6-12 tahun memiliki masalah emosi dan perilaku. Salah satu faktor yang dikaitkan dengan timbulnya masalah ini adalah kehidupan di kota besar yang penuh dengan tuntutan dan tekanan bagi perkembangan dan pertumbuhan anak dan remaja.

Berdasarkan data Kemenkes RI tahun 2018 prevalensi TB anak (kurang dari 15 tahun) mencapai $9 \%$ dari seluruh populasi TB di Indonesia yang didominasi oleh sosial ekonomi menegah kebawah. Hasil penelitian Erni dkk (2019) diwilayah Kerja Puskesmas Jakarta Pusat (Puskesmas Kecamatan Menteng dan Sawah Besar) dan Puskesmas Cakung, Jakarta Timur pada 91 responden didapatkan bahwa terdapat hubungan yang signifikan antara riwayat kontak dan status gizi terhadap kejadian tuberculosis pada anak. Selanjutnya saat dilakukan studi pendahuluan oleh peneliti 7 dari 10 anak mengalami masalah emosi dan perilaku yang abnormal dan 2 di antaranya borderline (ambang) dan 1 normal. Tujuh anak yang mengalami masalah emosi dan perilaku yang abnormal sering merasa khawatir, dan merasa ketakutan sering mudah marah, dan hal tersebut menjadi gangguan emosi dan perilaku sehingga, pentingnya mengetahui masalah emosi dan perilaku anak guna mendeteksi dini masalah/gangguan kesehatan mental pada anak serta dapat menjadi data dasar dalam menentukan langkah selanjutnya. Peran orang tua juga sangat dibutuhkan dalam perkembangan anak dan harus mengenali masalah/gangguan kesehatan mental pada anak agar adanya pencegahan dan pemulihan gangguan tersebut dan tidak berkelanjutan hingga anak tumbuh dewasa.

Setiap anak menunjukan gejala emosi dan perilaku yang berbeda-beda sehingga perlu adanya upaya peningkaan kesehatan anak untuk psikologi pada anak dan sebagai upaya promotif dan preventif kita terhadap psikologi anak maka dari itu peneliti ingin sekali meneliti Gambaran Masalah Emosi dan Perilaku Pada Anak Usia 3-15 Tahun dalam hubungannnya dengan kejadian TB anak di Wilayah Puskesmas Jakarta Pusat serta Puskesmas Jakarta Timur (Ernirita, 2020)

Adapun tujuan penelitian untuk mengidentifikasi masalah emosi dan perilaku pada penderita $\mathrm{TB}$ anak di Wilayah Puskesmas Jakarta Pusat dan Puskesmas Jakarta Timur

\section{METODE PENELITIAN}

Jenis Penelitian ini merupakan penelitian analitik dengan rancangan potong lintang/cross sectional, yang pengambilan datanya dilakukan pada bulan Maret - Juli tahun 2019. Adapun populasi dan besar sampel dalam penelitian ini adalah semua anak dengan usia 3-15 tahun yang memiliki riwayat kontak (baik kontak erat atau kontak serumah) dengan penderita TB dewasa dan belum mendapatkan PP INH yang tinggal wilayah Puskesmas Kecamatan Sawah Besar, Puskesmas Kecamatan Menteng, dan Puskesmas Kecamatan Cakung, berjumlah 91 responden. Instrumen penelitian TB anak menggunakan form TB.01 lalu dilakukan home visit untuk melakukan skrining dengan form TB. 15 lalu dilakukan observasi langsung pada anak untuk melihat ada tidaknya gejala klinis TB yang terjadi pada anak (Kemenkes RI, 2016).

Pengukuran status gizi dilakukan dengan menghitung $\mathrm{BB} / \mathrm{U}$ untuk anak kurang dari 5 tahun dan dengan IMT untuk anak usia $6-15$ tahun. Jika dari hasil observasi dengan form TB.15 menunjukkan adanya satu atau lebih gejala klinis TB, maka anak dilakukan pemeriksaan penunjang seperti uji 
tuberkulin, TCM atau rontgen. Setelah hasil pemeriksaan penunjang sudah keluar maka dilakukan skoring oleh dokter untuk melihat apakah anak tersebut terdiagnosis TB anak atau tidak (Kemenkes RI, 2016).

Instrumen untuk mengukur masalah emosi dan perilaku anak menggunakan SDQ (Strength and Difficulties Quistionnaire). SDQ adalah suatu alat ukur atau skala psikologi yang terdiri dari 25 item dengan lima dimensi yang akan diukur yaitu prososial (Pr), hiperaktif (H), Emosional (E), perilaku (C) dan hubungan dengan teman sebaya $(P)$. Kuesioner ini untuk mendeteksi dini masalah emosi dan perilaku pada anak usia 4-17 tahun. Secara umum terdapat 2 ranah penilaian, yaitu skor kesulitan, meliputi: Emosional (E) + Perilaku $(\mathrm{P})+$ Hiperaktif $(\mathrm{H})+$ Masalah hubungan teman sebaya (P) dan skor kekuatan, yaitu Prososial (Pr).

Skoring SDQ, terdiri dari 3 alternatif jawaban, yaitu: tidak benar bernilai 0 , agak benar nilai 1 , dan benar dengan nilai 2 kecuali pernyataan yang ada pada nomor 7, 11, 14, 21, dan 25 jawaban dari nomor tersebut keterbalikan dari nomor dari pernyataan yang lainnya karena, SDQ bukan alat diagnosis melainkan hanya alat deteksi dini yang mana ada 3 hasil yaitu normal, abnormal, (memiliki masalah perilaku dan emosi) kategori ini menjadi perhatian utama (Goodman, 1997).

\section{HASIL}

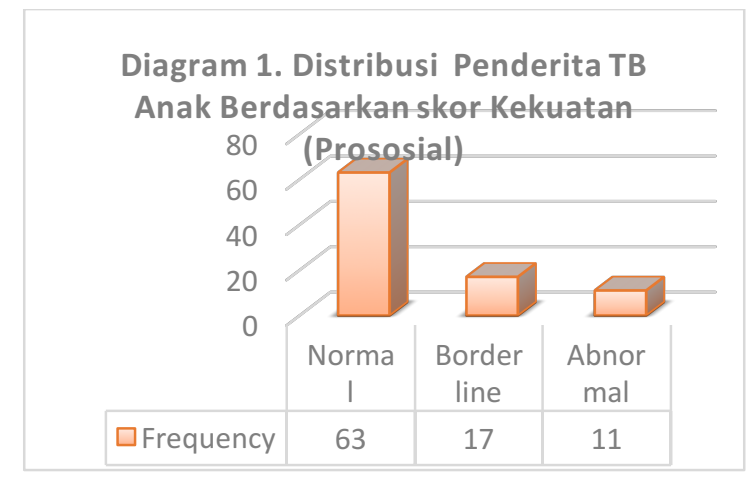

Pada diagram 1 menjelaskan bahwa distribusi penderita TB pada anak didapatkan 28 responden dengan skor kekuatan borderline dan abnormal.

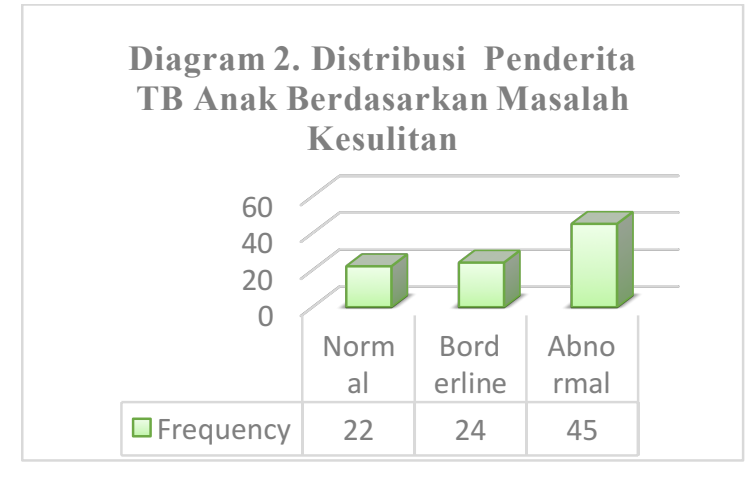

Diagram 2 menunjukkan untuk masalah kesulitan berhubungan dengan orang lain dalam kategori abnormal sebesar 45 anak.

Selama periode enam bulan didapatkan 91 responden yang memenuhi kriteria yang sudah ditentukan. Sebanyak $44 \%$ persen dari seluruh subjek penelitian berada pada usia hingga 12 tahun (usia sekolah) dan proporsi subjek penelitian dengan jenis kelamin laki-laki lebih banyak daripada perempuan. Karakteristik lainnya didapatkan riwayat kontak serumah memiliki proporsi terbesar dibanding kontak erat, dengan status gizi kurang sebesar 7,7\%, status kejadian TB positif sebesar 16,5\%, selanjutnya dijelaskan resiko masalah emosional (borderlineabnormal) sebesar 41,8\%, tingkah laku abnormal anak sebesar 72,5\%, hiperaktifitas yang abnormal (borderlineabnormal) sebesar $12,1 \%$ serta masalah hubungan dengan teman sebaya yang abnormal diperoleh $82,4 \%$ (Tabel 1) 
Tabel 1. Distribusi Responden menurut Karakteristik Variabel $(\mathbf{n}=91)$

\begin{tabular}{llcc}
\hline \multirow{2}{*}{ Karakteristik Variabel } & & \multicolumn{2}{c}{ Jumlah } \\
\cline { 2 - 4 } 1. Umur & & $\mathbf{n}$ & $\mathbf{\%}$ \\
& Pra sekolah & 36 & 39,5 \\
2. Jenis kelamin & Sekolah & 49 & 44 \\
& Remaja & 15 & 16,5 \\
3. Riwayat Kontak & Laki-laki & 42 & 46,2 \\
& Perempuan & 49 & 53,8 \\
4. Status Gizi & Kontak Erat & 34 & 37,4 \\
& Kontak Serumah & 57 & 62,6 \\
5. Status TB & Kurang & 7 & 7,7 \\
& Normal & 84 & 92,3 \\
6. Masalah Emosional & Positif & 15 & 16,5 \\
& Negatif & 76 & 83,5 \\
7. Masalah Tingkah laku & Normal & 53 & 58,2 \\
& Borderline & 22 & 24,2 \\
8. Hiperaktifitas & Abnormal & 16 & 17,6 \\
& Normal & 10 & 11 \\
9. Masalah Hub. Teman Sebaya & Borderline & 15 & 16,5 \\
& Abnormal & 66 & 72,5 \\
& Normal & 80 & 89,9 \\
& Borderline & 9 & 9,9 \\
& Abnormal & 2 & 2,2 \\
& Normal & 8 & 8,8 \\
& Borderline & 8 & 8,8 \\
& Abnormal & 75 & 82,4 \\
\hline
\end{tabular}

Tabel 2. Hasil Analisis Distribusi Skor SDQ Berdasarkan Usia Responden $(\mathbf{n}=91)$

\begin{tabular}{|c|c|c|c|c|c|c|c|c|}
\hline \multirow{2}{*}{ Skor SDQ } & \multicolumn{2}{|c|}{ Pra Sekolah } & \multicolumn{2}{|c|}{ Sekolah } & \multicolumn{2}{|c|}{ Remaja } & \multicolumn{2}{|c|}{ Total } \\
\hline & $\mathbf{n}$ & $\%$ & $\mathbf{n}$ & $\%$ & $\mathbf{n}$ & $\%$ & $\mathbf{n}$ & $\%$ \\
\hline \multicolumn{9}{|l|}{ 1. Emosional } \\
\hline Normal & 22 & 41.5 & 21 & 39,6 & 10 & 18,9 & 53 & 100 \\
\hline Borderline & 6 & 27,3 & 12 & 54,5 & 4 & 18,2 & 22 & 100 \\
\hline Abnormal & 8 & 50 & 7 & 43,8 & 1 & 6,3 & 16 & 100 \\
\hline \multicolumn{9}{|l|}{ 2. Tingkah laku } \\
\hline Normal & 5 & 50 & 4 & 40 & 1 & 10 & 8 & 100 \\
\hline Borderline & 2 & 13,3 & 5 & 60 & 4 & 26,7 & 8 & 100 \\
\hline Abnormal & 29 & 43,9 & 27 & 40,9 & 10 & 15,2 & 75 & 100 \\
\hline \multicolumn{9}{|l|}{ 3. Hiperaktifitas } \\
\hline Normal & 30 & 37,5 & 35 & 43,8 & 15 & 18,8 & 80 & 100 \\
\hline Borderline & 5 & 55,6 & 4 & 44,4 & 0 & 0 & 9 & 100 \\
\hline Abnormal & 1 & 50 & 1 & 50 & 0 & 0 & 2 & 100 \\
\hline \multicolumn{9}{|l|}{ 4. Teman Sebaya } \\
\hline Normal & 2 & 25 & 4 & 50 & 2 & 25 & 8 & 100 \\
\hline Borderline & 5 & 62,5 & 3 & 37,5 & 0 & 0 & 8 & 100 \\
\hline Abnormal & 29 & 38,7 & 33 & 44 & 13 & 17,3 & 75 & 100 \\
\hline \multicolumn{9}{|l|}{ 5. Total Skor Kesulitan } \\
\hline Normal & 7 & 31,8 & 10 & 45,5 & 10 & 18,9 & 27 & 100 \\
\hline Borderline & 9 & 37,5 & 12 & 50 & 4 & 18,2 & 25 & 100 \\
\hline Abnormal & 20 & 44,4 & 18 & 40 & 1 & 6,3 & 39 & 100 \\
\hline \multicolumn{9}{|l|}{ 6. Skor Kekuatan/Prososial } \\
\hline Normal & 21 & 33,3 & 30 & 47,6 & 12 & 19 & 63 & 100 \\
\hline Borderline & 9 & 52,9 & 6 & 35,3 & 2 & 11,8 & 17 & 100 \\
\hline Abnormal & 6 & 54,5 & 4 & 36,4 & 1 & 9,1 & 11 & 100 \\
\hline
\end{tabular}


Tabel 3. Hasil Analisis Distribusi Skor SDQ Berdasarkan Jenis Kelamin

$$
(\mathbf{n}=\mathbf{9 1})
$$

\begin{tabular}{lcccccc}
\hline \multicolumn{1}{c}{ Skor SDQ } & \multicolumn{2}{c}{ Laki-laki } & \multicolumn{2}{c}{ Perempuan } & \multicolumn{2}{c}{ Total } \\
& N & \% & n & \% & n & \% \\
\hline 1. Emosional & & & & & & \\
$\quad$ Normal & 26 & 49.1 & 27 & 50,9 & 53 & 100 \\
$\quad$ Borderline & 12 & 54,5 & 10 & 45,5 & 22 & 100 \\
$\quad$ Abnormal & 4 & 25 & 12 & 75 & 16 & 100 \\
2. Tingkah laku & & & & & & \\
$\quad$ Normal & 4 & 50 & 6 & 50 & 10 & 100 \\
$\quad$ Borderline & 10 & 66,7 & 5 & 33,3 & 15 & 100 \\
$\quad$ Abnormal & 28 & 42,4 & 38 & 57,6 & 66 & 100 \\
3. Hiperaktifitas & & & & & & \\
$\quad$ Normal & 36 & 45 & 44 & 55 & 80 & 100 \\
$\quad$ Borderline & 5 & 55,6 & 4 & 44,4 & 9 & 100 \\
$\quad$ Abnormal & 1 & 50 & 1 & 50 & 2 & 100 \\
4. Teman Sebaya & & & & & & \\
$\quad$ Normal & 5 & 52,5 & 3 & 47,5 & 8 & 100 \\
$\quad$ Borderline & 2 & 25 & 6 & 75 & 8 & 100 \\
$\quad$ Abnormal & 35 & 46,7 & 40 & 53,3 & 75 & 100 \\
5. Total Skor Kesulitan & & & & & & \\
$\quad$ Normal & 9 & 40,9 & 13 & 59,1 & 22 & 100 \\
$\quad$ Borderline & 10 & 41,7 & 14 & 58,3 & 24 & 100 \\
$\quad$ Abnormal & 23 & 51,2 & 22 & 48,8 & 45 & 100 \\
6. Skor Kekuatan/Prososial & & & & & & \\
$\quad$ Normal & 27 & 42,9 & 36 & 47,1 & 63 & 100 \\
$\quad$ Borderline & 10 & 58,8 & 7 & 41,2 & 17 & 100 \\
$\quad$ Abnormal & 5 & 45,5 & 6 & 54,5 & 11 & 100 \\
\hline$\quad$ & & & & & &
\end{tabular}

Tabel 4. Hasil Analisis Distribusi Skore SDQ Berdasarkan Kovariat Responden (Status Gizi, Riwayat Kontak dan Status TB) $(n=91)$

\begin{tabular}{|c|c|c|c|c|c|c|c|c|c|c|c|c|}
\hline \multirow{3}{*}{ Skor SDQ } & \multicolumn{4}{|c|}{ Riwayat Kontak } & \multicolumn{4}{|c|}{ Status Gizi } & \multicolumn{4}{|c|}{ Status TB } \\
\hline & \multicolumn{2}{|c|}{ Erat } & \multicolumn{2}{|c|}{ Serumah } & \multicolumn{2}{|c|}{ Kurang } & \multicolumn{2}{|c|}{ Normal } & \multicolumn{2}{|c|}{ Positif } & \multicolumn{2}{|c|}{ Negatif } \\
\hline & $\mathbf{n}$ & $\%$ & $\mathbf{n}$ & $\%$ & $\mathbf{n}$ & $\%$ & $\mathbf{n}$ & $\%$ & $\mathbf{n}$ & $\%$ & $\mathbf{n}$ & $\%$ \\
\hline \multicolumn{13}{|l|}{ 1. Emosional } \\
\hline Normal & 27 & 43,4 & 30 & 56,6 & 3 & 5,7 & 50 & 94,3 & 10 & 18,9 & 43 & 81,1 \\
\hline Borderline & 8 & 36,4 & 14 & 63,6 & 1 & 4,5 & 31 & 95,5 & 3 & 13,6 & 19 & 86,4 \\
\hline Abnormal & 3 & 18,8 & 13 & 81,2 & 3 & 18,8 & 12 & 81,3 & 2 & 12,5 & 14 & 87,5 \\
\hline \multicolumn{13}{|l|}{ 2. Tingkah laku } \\
\hline Normal & 0 & 0 & 10 & 100 & 0 & 0 & 10 & 100 & 2 & 20 & 8 & 80 \\
\hline Borderline & 6 & 40 & 9 & 60 & 0 & 0 & 15 & 100 & 0 & 0 & 15 & 100 \\
\hline Abnormal & 28 & 42,4 & 38 & 57,6 & 7 & 10,6 & 59 & 89.4 & 13 & 19,7 & 53 & 80,3 \\
\hline \multicolumn{13}{|l|}{ 3. Hiperaktifitas } \\
\hline Normal & 32 & 40 & 48 & 60 & 7 & 8,8 & 73 & 91,2 & 14 & 17,5 & 65 & 82,5 \\
\hline Borderline & 2 & 22,2 & 7 & 87,8 & 0 & 0 & 9 & 100 & 1 & 11,1 & 8 & 88,9 \\
\hline Abnormal & 0 & 0 & 2 & 100 & 0 & 0 & 2 & 100 & 0 & 0 & 2 & 100 \\
\hline \multicolumn{13}{|l|}{ 4. Teman Sebaya } \\
\hline Normal & 1 & 12,5 & 7 & 87,5 & 0 & 0 & 8 & 100 & 1 & 12,5 & 7 & 87,5 \\
\hline Borderline & 3 & 37,5 & 5 & 62,5 & 1 & 12,5 & 7 & 87,5 & 2 & 25 & 6 & 75 \\
\hline Abnormal & 30 & 40 & 45 & 60 & 6 & 8 & 69 & 92 & 12 & 16 & 63 & 84 \\
\hline \multicolumn{13}{|l|}{ 5. Total Kesulitan } \\
\hline Normal & 6 & 27,3 & 16 & 82,7 & 1 & 4,5 & 21 & 95,5 & 4 & 18,2 & 18 & 81,8 \\
\hline Borderline & 10 & 41,7 & 14 & 58,3 & 1 & 4,2 & 23 & 95,8 & 2 & 8,3 & 22 & 91,7 \\
\hline Abnormal & 18 & 40 & 18 & 60 & 5 & 11,1 & 40 & 89,9 & 9 & 20 & 36 & 80 \\
\hline \multicolumn{13}{|l|}{ 6. Skor Prososial } \\
\hline Normal & 25 & 39,7 & 38 & 47,6 & 1 & 1,6 & 62 & 98,4 & 9 & 14,3 & 54 & 85,7 \\
\hline Borderline & 6 & 35,3 & 11 & 35,3 & 3 & 17,8 & 14 & 82,2 & 3 & 17,6 & 14 & 82,4 \\
\hline Abnormal & 3 & 27,3 & 8 & 36,4 & 3 & 27,3 & 8 & 72,7 & 3 & 27,3 & 8 & 72,7 \\
\hline
\end{tabular}




\section{PEMBAHASAN}

Penelitian ini melibatkan 91 responden penderita TB pada anak yang dianalisis di wilayah kerja Puskesmas Jakarta Pusat dan Cakung Jakarta Timur. Hasil penelitian menunjukkan rata-rata umur responden penderita TB pada anak adalah 8,2 tahun $(95 \%$ CI : 7,48 - 8,91), dengan standar deviasi 3,42 tahun. Umur termuda adalah 4 tahun dan yang tertua adalah 14 tahun. Kelompok usia terbanyak adalah usia sekolah (dibawah 12 tahun) dengan masalah yang berhubungan dengan tingkah laku, sebagian kecil teman sebaya, kesulitan dan kekuatan sebagai masalah utama. Anak usia sekolah akan memasuki tahap Industrial vs Inferioritas dimana anak yang sebelumnya banyak berada di lingkungan keluarga, pada tahap ini anak akan banyak keluar ke lingkungan sekolah (Sunaryo, 2004). Lebih lanjut hal ini sejalan dengan penelitian penelitian Chika, dkk (2016): dengan responden terbesar adalah diusia sekolah

Variabel jenis kelamin perempuan memiliki nilai abnormal pada tingkah laku lebih banyak disbanding laki-laki, kondisi ini tidak sejalan dengan hasil penelitian Ehsan dkk (2009) tentang prevalensi masalah emosional dan perilaku dimana masalah tingkah laku lebih banyak dialami oleh laki-laki dibandingkan perempuan. Namun sejalan dengan penelitian Chika dkk (2016) yang menyatakan bahwa mayoritas responden dengan jenis kelamin perempuan sebanyak $53 \%$.

Perempuan secara umum lebih rentan terhadap penyakit, dikarenakan ketika perempuan terpapar suatu zat asing (alergen, virus, bakteri), sel mast akan melepaskan lebih banyak zat inflamasi yang dapat memicu respon kekebalan yang lebih agresif seperti anafilaksis. Sel mast pada perempuan membuat dan menyimpan lebih banyak zat inflamasi seperti histamin, serotonin, dan protase dibandingkan sel mast dari laki - laki.

Perbedaan masalah emosi dan perilaku pada jenis kelamin ini berkaitan dengan adanya perbedaan hormonal pada laki-laki dan perempuan, disamping itu juga adanya perbedaan terhadap tuntutan sosial terhadap laki-laki atau perempuan. Tingkah laku yang tampak pada kegiatan anak/ organisme lainnya dipengaruhi oleh faktor genetik dan ringan. Secara umum dapat dikatakan bahwa faktor genetik dan lingkungan ini merupakan penentu dari perilaku seseorang termasuk perilaku manusia. Faktor keturunan atau hereditas adalah merupakan konsepsi dasar atau model untuk pengembangan perilaku seseorang. Sedangkan lingkungan merupakan kondisi atau lahan untuk pengembangan perilaku tersebut (Notoatmodjo, 2010).

Begitu juga untuk masalah hubungan dengan teman sebaya merupakan masalah yang cukup serius, terutama anak perempuan yang memasuki usia remaja. Teman sebaya bagi anak yang berusia 9-13 tahun, paling besar pengaruhnya terhadap kehidupan mereka sehari-hari disamping orangtua (Baumeister \& Harter, 2007). Dengan adanya masalah hubungan dengan teman sebaya ini tentunya berdampak dalam fungsi keseharian anak dan remaja sehingga membuat orangtua harus lebih waspada dalam interaksi sehari-hari.

$\begin{array}{ccr}\text { Skala } & \text { kesulitan } & \text { dan } \\ \text { kekuatan/prososial } & \text { terbanyak } & \text { pada }\end{array}$
kelompok pra sekolah dan sekolah (usia 3 12 tahun) dimana relative seimbang antara anak lelaki dan perempuan prevalensinya. Anak usia prasekolah memilki tugas perkembangan anak-anak awal adalah: 1 . Belajar keterampilan fisik yang diperlukan untuk bermain 2. Membina sikap yang sehat (positif) terhadap diri sendiri sebagai seorang individu yang berkembang, seperti kesadarn tentang harga diri dan kemampuan diri dan 3. Belajar bergaul dengan teman-temannya (Hurlock, 1993), selanjutnya pada anak usia sekolah juga anak mulai memasuki dunia yang nyata dengan menyelesaikan tanggung jawabnya dan mereka disiapkan untuk memasuki masa sekolah. Perubahan kognitif pada anak usia sekolah adalah pada kemampuan untuk berpikir dengan cara logis tentang di 
sini dan saat ini, bukan tentang hal yang bersifat abstraksi. Pemikiran anak usia sekolah tidak lagi didominasi oleh persepsinya dan sekaligus kemampuan untuk memahami dunia secara luas (Piaget dalam Wong, Hockenberry Eaton, Winkelstein, \& Schwartz, 2008). Hal ini dapat menimbulkan perubahan terhadap masalah emosi dan perilaku dalam kaitannya dengan hubungan mereka terhadap teman-teman baru (Verhulst, 2004).

Anak usia sekolah akan memasuki tahap Industrial vs Inferioritas dimana anak yang sebelumnya banyak berada di lingkungan keluarga, pada tahap ini anak akan banyak keluar ke lingkungan sekolah (Sunaryo, 2004). Skrining juga perlu dilakukan di tingkat sekolah dimana harus ada kerjasama antara pihak puskesmas dengan pihak sekolah agar area penjaringan TB semakin luas. Mengingat juga bahwa intensitas anak yang cukup lama berada di lingkungan sekolah. Karena TB juga dapat menular di lingkungan sekolah, hal ini dibuktikan dengan ditemukannya pasien TB anak yang terjaring di sekolah, dimana pasien tersebut dikelurganya tidak ada yang menderita TB sebelumnya (Wiguna, 2010).

Analisis tabel silang dari masalah emosi dan perilaku dengan kovariat (status gizi, riwayat kontak dan status TB) pada penderita TB anak nilai abnormal lebih banyak berhubungan dengan tingkah laku, teman sebaya dan kesulitan diwilayah kerja Puskesmas Jakarta Pusat dan Timur.

Nilai abnormal pada tingkah laku lebih banyak terdapat pada penderita TB anak dengan status gizi normal, hasil ini tidak sesuai dengan penelitian Chika, dkk (2016) yang menunjukkan bahwa mayoritas responden memiliki status gizi kurang yang berjumlah 39 responden $(57,4 \%)$ dan juga berbeda dengan penelitian Putra, dkk (2018) yang menunjukkan mayoritas responden memiliki status gizi kurang sebanyak 17 responden $(65,4 \%)$. Status gizi juga erat kaitannya dengan penyakit TB baik pada dewasa maupun anak - anak. Penyakit TB paru juga berkontribusi dalam terjadinya status gizi buruk karena dengan adanya penyakit TB paru maka akan mengganggu proses perjalanan maupun penyerapan nutrisi dalam tubuh (Patiung dkk, 2014).

Masalah yang berhubungan dengan teman sebaya bagi penderita $\mathrm{TB}$ anak, paling besar pengaruhnya terhadap kehidupan mereka sehari-hari disamping orangtua. ${ }^{6}$ Dengan adanya masalah hubungan dengan teman sebaya ini tentunya berdampak dalam fungsi keseharian anak dan remaja sehingga membuat sianak harus lebih waspada dalam interaksi sehari-hari termasuk dalam berinteraksi dengan teman sebayanya, jangan sampai menjadi penghambat dalam memenuhi asupan gizinya

Masalah emosi dan perilaku menurut skor kesulitan pada penderita TB anak. Hakekatnya penyakit TB adalah penyakit kronis, yang bila tidak ditangani serius akan mengakibatkan terjadinya gangguan mental emosional sebesar 3,9 kali dibanding yang tidak mengalami penyakit kronis (Widakdo, 2013). Pemenuhan gizi yang seimbang pada pasien dengan penyakit kronis, dapat menekan kesulitan penderita penyakit TB pada anak

Status gizi yang buruk dapat mempengaruhi tanggapan tubuh berupa pembentukan antibody dan limfosit terhadap adanya kuman penyakit termasuk salah satunya TB. Pembentukan antibody dan limfosit memerlukan bahan yang berasal dari protein dan karbohidrat. Status gizi anak yang baik, belum dapat menentukan daya tahan tubuh anak akan baik juga, kemungkinan anak terinfeksi TB bukan karena status gizinya saja tapi bisa juga dipengaruhi oleh seringnya anak kontak dengan penderita TB dewasa. Kondisi gizi normal juga dapat berisiko menjadi gizi kurang. Hal ini dikarenakan dampak lain dari infeksi kuman TB yang sering timbul yaitu kehilangan nafsu makan, penurunan berat badan, serta efek samping OAT seperti mual dan muntah. Jika intake nutrisi yang tidak adekuat maka 
anak dengan gizi normal akan berubah menjadi gizi kurang atau bahkan gizi buruk, secara tidak langsung dapat berkaitan dengan perubahan perilaku sebagai akibat kekhawtiran yang berlebih (Ernirita, 2020).

Riwayat kontak menjadi faktor resiko yang paling sering menyebabkan timbulnya penyakit TB (Kemenkes RI, 2016). Pravelensi infeksi tuberkulosis pada anak yang tinggal serumah dengan pasien TB dewasa lebih tinggi dibandingkan dengan infeksi di populasi umum (Anasyia \& Chatarina, 2015). Investigasi kontak juga diutamakan bagi anak yang tinggal serumah dengan pasien TB dewasa sehingga hasil yang didapatkanpun lebih banyak anak yang memiliki kontak serumah dibandingkan dengan kontak erat dengan pertimbangan bahwa anak yang memiliki kontak serumah memiliki resiko yang lebih besar untuk terkena TB. Investigasi kontak pada anak dilakukan pada kelompok umur $0-14$ tahun dan yang menjadi prioritas utama adalah yang memiliki riwayat kontak baik dengan pasien TB dewasa infeksius, pasien TB RO, maupun pasien TB yang terinfeksi HIV. Hal ini menyebabkan kemungkinan lebih banyak ditemukannya anak yang memiliki riwayat kontak serumah dibandingkan dengan kontak erat. Data yang diambil berdasarkan TB.01 dimana yang tercantum adalah daftar kontak serumah, jika mengambilan data dilakukan dengan ACF (active case finding) maka memungkinkan untuk lebih banyak distribusi kontak erat karena tidak berdasarkan dari daftar pasien TB dewasa.

Adanya pola kontak yang beragam disekitar rumah dari cara bersosialisai atau memenuhi kebutuhan hidupnya memungkinkan terjadinya masalah perilaku, berteman dengan sebaya serta mengalami kesulitan untuk tumbuh dan berkembang secara proporsional dan wajar Masalah emosi dan perilaku berdasrkan status TB anak yang dua makna, yaitu sakit dan rentan. Dalam SDQ mencakup masalah depresi dan juga cemas yang berkaitan dengan perilaku, hubungan teman sebaya dan kesulitannya. Garland (2001) melaporkan bahwa $33,6 \%$ anak yang datang ke pusat pelayanan kesehatan jiwa dengan masalah emosi. Angka yang didapatkan dalam penelitian kami sedikit lebih tinggi daripada angka yang didapatkan oleh penelitian yang dilakukan oleh Garland.

Hasil penelitian ini hampir sama dengan penelitian Serrano-Blanco et al (2010) pada 3.815 pasien yang berasal dari Layanan Kesehatan Primer di Spanyol yang menemukan bahwa $45 \%$ responden pernah mengalami gangguan mental emosional dan $30 \%$ mengalami gangguan mental emosional dalam satu tahun terakhir.Tingginya kejadian gangguan mental emosional ini sangat berkaitan dengan kondisi penyakit kronis yang dialami oleh responden ${ }^{8}$ Kondisi ini mengkhawatirkan karena secara fisik maupun sosial responden yang mengalami gangguan mental emosional dapat memperparah gangguan fisik penyakit kronis yang dialaminya (TB positif). Kondisi ini juga dapat mengganggu hubungan individu dengan lingkungannya yang berpotensi menjadikan individu tersebut mengalami maslah kejiwaan. Gangguan jiwa adalah suatu perubahan pada fungsi jiwa yang menyebabkan adanya gangguan pada fungsi jiwa yaitu menimbulkan penderitaan atau hambatan dalam melaksanakan peran sosial (Baumeister \& Harter, 2007).

Masalah kesulitan merupakan masalah perilaku yang dijumpai pada anak dan remaja dengan proporsi yang cukup besar terutama pada kelompok remaja. Namun dijumpai proporsi yang lebih tinggi pada anak di bawah usia 12 tahun, dan hasil ini berbeda dengan berbagai hasil yang ditemukan dalam penelitian di luar negeri (Ernirita, 2020; Baumeister\& Harter, 2007). Beberapa hal yang mungkin berkaitan dengan kondisi tersebut adalah perbedan tempat penelitian merupakan perbandingan puskesmas dengan rujukkannya umtuk kerumah sakit yang sudah lama memberikan pelayanan 
kesehatan jiwa secara khusus sehingga lebih banyak anak dengan masalah kesulitan berkonsultasi; orangtua sudah lebih waspada dengan berbagai masalah kesulitan sehingga mereka mencari pertolongan yang lebih dini sebelum anak memasuki usia remaja; adanya penggeseran perkembangan masa remaja ke usia yang lebih awal sehingga masalah sudah tampak di periode remaja awal.

\section{SIMPULAN}

Subyek penelitian terbanyak adalah laki-laki namun berdasarkan skor SDQ yang abnormal terbesar adalah responden berjenis kelamin perempuan dengan proporsi abnormal terjadi kelompok usia pra sekolah - sekolah, yaitu untuk masalah tingkah laku, hubungan teman sebaya. dan prososial sedangkan laki-laki hanya pada masalah terkait dengan kesulitan dalam bersosialisasi saja.

Proporsi terbesar abnormal pada analisis distribusi skor masalah dan perilaku penderita TB pada anak dengan kovariat (Status Gizi, Riwayat kontak dan Status TB), yaitu : untuk masalah tingkah laku teman sebaya dan skor kesulitan

\section{SARAN}

SDQ memanglah bukan instrument untuk mengukur atau menentukan diagnose terhadap kesehatan jiwa namun screening ini dapat menjadi rujukan orang tua atau guru atau puskesmas guna menindak lanjuti program dalam mengantisipasi gangguan kesehatan mental

\section{DAFTAR PUSTAKA}

Baumeister H, Härter M. (2007). Prevalence of mental disorders based on general population. Surveys. Social Psychiatry and Psychiatric Epidemiology. (42): 537-46.

Ernirit. (2020) Riwayat Kontak Dan Status Gizi Buruk Dapat Meningkatkan Kejadian Tuberkulosis Pada Anak. Jurnal Kesehatan Masyarakat Khatulistiwa. 7(1): 20-29

Garland AF. (2001). Prevalence of psychiatric disorders in youth across five sectors of care. J Am Acad Child Adolesc Psy. (40):409-18.

Goodman R. (1997). The Stregth and Difficulties Questionaire: A research note. J Child Psychol Psychiatry. (38) : 581-6.

Kemenkes RI. (2016). Petunjuk teknis manajemen dan tatalaksana TB anak. Jakarta: Kementerian Kesehatan RI.

Notoadmodjo. (2010). Teori dan Pengukuran Pengetahuan, Sikap Dan Perilaku Manusia

Pandia veranita. (2014). Instrumen Deteksi Dini Gangguan Mental Emosional Pada Anak dan Remaja. Konas Psikiatri Komunitas, Bandung.

Serrano-Blanco A, Palao DJ, Luciano JV, Pinto-Meza A, Luja L, Fernandez A, et al. (2010). Prevalence of mental disorders in primary care: results from the diagnosis and treatment of mental disorders in primary care study (DASMAP). Social Psychiatry and Psychiatric Epidemiology. (45): 201-10.

Verhulst FC. (2004). Epidemiology as a basis for conception and planning for services. Dalam: Remschmidt $H$, Belfer ML, Goodyer I, penyunting. Facilitating pathways care, treatment and prevention in child and adolescent mental health. Germany: Springer.

Widakdo G, Besral. (2013). Efek penyakit Kronis Terhadap Gangguan Mental Emosional. Jurnal Kesehatan Masyarakat. 7(7): 309-316

Wiguna. (2010). Masalah Emosi dan Perilaku pada Anak dan Remaja di Poliklinik Jiwa Anak dan Remaja RSUPN dr. Ciptomangunkusumo (RSCM), Jakarta. Sari Pediatri. 12 (4): $270-277$ 